Jurnal Keperawatan Silampari

Volume 5, Nomor 1, Desember 2021

e-ISSN: 2581-1975

p-ISSN: 2597-7482

DOI: https://doi.org/10.31539/jks.v5i1.2866

IPMERpE

\title{
PENGEMBANGAN MEDIA PENDIDIKAN KESEHATAN AUDIO VISUAL PADA PROGRAM PENDIDIKAN ANAK USIA DINI - INTEGRASI CEGAH STUNTING (PAUD-INCASTING) ANAK USIA PRASEKOLAH
}

\author{
Titih Huriah $^{1}$, Azzahra Dwi Sintaningrum ${ }^{2}$, Andri Hermawan ${ }^{3}$ \\ Universitas Muhammadiyah Yogyakarta ${ }^{1,2,3}$ \\ titih.huriah@umy.ac.id ${ }^{1}$
}

\begin{abstract}
ABSTRAK
Penelitian ini bertujuan untuk mengembangkan media edukasi audio visual pada program Pendidikan Anak Usia Dini (PAUD) untuk mencegah stunting pada anak prasekolah. Desain penelitian yang digunakan adalah Research and Development (R\&D) dengan model pengembangan ADDIE (Analysis, Design, Development or Production, Implementation or Delivery dan Evaluations). Hasil penelitian menunjukkan bahwa mayoritas resonden berjenis kelamin laki-laki yaitu sebanyak 11 responden $(55 \%)$ dan mayoritas berpendidikan SMA yaitu sebanyak 10 responden (50\%). Terdapat peningkatan asupan makan total, makan pagi dan makan malam sedangkan pada asupan makan siang tidak terlihat perbedaan. Hasil edukasi dengan video terlihat terdapat pengaruh terhadap asupan makan, perilaku cuci tangan dengan $\mathrm{p}$ value $<0,05$ namun belum terdapat perubahan pada status gizi anak. Simpulan, pengembangan media edukasi audio visual pada program PAUD dapat mencegah stunting pada anak prasekolah dengan indikator peningkatan asupan makan, PHBS perilaku cuci tangan dan status gizi anak.
\end{abstract}

Kata Kunci: Audio Visual, Perilaku Cuci Tangan, Status Gizi, Stunting, Video Edukasi

\begin{abstract}
This study aims to develop audio-visual educational media in the Early Childhood Education (PAUD) program to prevent stunting in preschool children. The research design used is Research and Development $(R \& D)$ with the ADDIE development model (Analysis, Design, Development or Production, Implementation or Delivery and Evaluations). The results showed that most resonances were male, as many as 11 respondents (55\%), and the highest was SMA, as many as ten respondents (50\%). There was an increase in total food intake, breakfast, and dinner, while lunch intake did not differ. The results of education with videos show an influence on food intake and handwashing behavior with a p-value <0.05, but there has been no change in the nutritional status of children. In conclusion, the development of audio-visual educational media in the PAUD program can prevent stunting in preschool children with indicators of increasing food intake, PHBS handwashing behavior, and children's nutritional status.
\end{abstract}

Keywords: Audiovisual, Handwashing Behavior, Nutritional Status, Stunting, Educational Video 


\section{PENDAHULUAN}

Salah satu masalah gizi yang menjadi perhatian utama di Indonesia adalah masih tingginya anak balita pendek (stunting) (Kemenkes RI, 2018). Stunting yaitu suatu kondisi kurangnya gizi secara kronis yang disebabkan oleh multifaktorial dalam waktu yang lama, sehingga berdampak pada masalah pertumbuhan pada anak, seperti tinggi badan yang lebih rendah atau pendek (kerdil) dari pertumbuhan usianya (Huriah et al., 2021; Kemenkes RI, 2019; Titaley et al., 2019). Kondisi ini akan sangat mempengaruhi populasi anak dimana 156 juta anak di dunia akan terdampak karena gangguan pertumbuhan (Perkins et al., 2017).

Pada tahun 2018, stunting mempengaruhi 21,9\% anak di bawah 5 tahun secara global yang setara dengan 149 juta anak di seluruh dunia (Vasquez \& Daher, 2019). WHO (2017) menyatakan data prevalensi balita stunting di Indonesia termasuk ke dalam negara ke tiga dengan prevalensi tertinggi di regional Asia Tenggara atau South-East Asia Regional (SEAR). Rata-rata prevalensi balita stunting di Indonesia tahun 2005-2017 adalah 36,4\% (WHO, 2019). Prevalensi balita yang mengalami stunting di wilayah Yogyakarta pada tahun 2018 yaitu sangat pendek sebesar 6,3\% dan pendek sebesar 15,1\% (Kemenkes, 2019). Laporan Pemantauan Status Gizi (PSG) Puskesmas Kota Yogyakarta tahun 2019 menyatakan bahwa persentase balita stunting di Yogyakarta yaitu 11,3\% balita pendek dan sangat pendek (Dinas Kesehatan Yogyakarta, 2020).

Upaya yang dapat dilakukan untuk meningkatkan kesehatan dan perkembangan anak adalah dengan dengan memberikan stimulasi dini (Hartinger et al., 2020). Stimulasi mempunyai peran penting untuk meningkatkan pertumbuhan dan perkembangan anak, terutama fungsi kognitif, afektif dan psikomotor (Hati \& Lestari, 2016). Pada penelitian yang dilakukan (Siswina et al., 2016) menunjukkan stimulasi sangat berpengaruh terhadap peningkatan tumbuh kembang dan kecerdasan anak sehingga anak usia prasekolah dapat terhindar dari stunting. Stimulasi yang dapat diberikan kepada anak prasekolah ialah dengan menggunakan media audio visual. Media audio visual memegang peranan yang cukup penting dalam proses pemberian stimulasi karena media ini dapat memperlancar pemahaman serta memperkuat ingatan anak prasekolah karena sangat menarik (Prasko et al., 2016).

Media audio visual adalah media yang dipaparkan dalam bentuk suara dan gambar yang mampu merangsang pikiran, perasaan, perhatian, serta kemampuan anak (Astuti, 2018). Selain itu, media audio visual juga memiliki peran yang penting dalam mengembangkan fungsi kognitif anak (Mesiono et al., 2020). Beberapa penelitian sebelumnya oleh Adawiyah et al., (2019) mendapatkan bahwa edukasi gizi dengan media video dapat meningkatkan pemahaman gizi pada anak usia 5-6 tahun dengan efektif. Dalam penelitiannya, Adawiyah menggunakan video yang sudah ada kemudian digunakan kembali untuk melakukan intervensi. Namun, penelitian ini berfokus pada pengembangan media audio visual pada program PAUD untuk mencegah stunting anak prasekolah. Peneliti berharap dengan adanya pengembangan media audio visual pada program PAUD dapat meningkatkan fungsi kognitif anak sehingga dapat mengurangi kejadian stunting pada balita.

\section{METODE PENELITIAN}

Pengembangan media audio visual ini merupakan penelitian pengembangan atau biasa disebut dengan Research and Development (R\&D). Model pengembangan yang digunakan pada penelitian ini adalah model pengembangan ADDIE (Analysis, Design, Development, Implementations, Evaluations). Tim peneliti terlibat sebagai editor video dan 
voice actor. Video edukasi yang dikembangkan berupa animasi gambar bergerak yang diisi dengan penjelasan melalui suara.

Peneliti berhasil mengembangkan dua video edukasi utnuk pencegahan stunting pada anak usia prasekolah. Video pertama berjudul "Mari Kita Cuci Tangan" berdurasi 2 menit 29 detik. Video kedua berjudul "Aku Tahu Isi Mangkuk Ku!" berdurasi 4 menit 15 detik. Kedua video telah diupload peneliti di akun Youtube peneliti sehingga anak bisa memutar ulang video tersebut. Efektifitas dari video didapatkan melalui pemberian intervensi pemberian edukasi secara langsung ke anak usia prasekolah dengan setting PAUD. Penelitian dilakukan di PAUD KB Aisyiyah Surya Melati Bantul. Waktu Penelitian dilaksanakan pada bulan Maret - April 2021.

Perangkat keras (hardware) yang digunakan dalam penelitian ini terdiri dari laptop dengan processor intel core i5, hardisk eksternal 1 terabyte, earphone, microphone, keyboard serta mouse. Perangkat lunak (software) yang digunakan dalam penelitian ini terdiri dari sistem operasi Windows; Microsoft Power Point, Adobe Premiere Pro dan Adobe After Effect untuk editing video; Adobe Photosop dan Adobe Illustrator untuk editing gambar animasi; serta Microsoft Word untuk membuat laporan penelitian.

Video edukasi telah melalui uji validitas dengan menggunakan formula gregory dari tiga orang ahli yaitu ahli promosi kesehatan, dokter anak dan ahli komunikasi. Uji validitas dari video edukasi terbagi atas tiga aspek utama. Adapun tiga aspek tersebut yaitu: (1) Validasi ahli berdasarkan aspek pendidikan, dalam hal ini akan terkait dengan kesesuaian dengan pembelajaran, isi materi, interaksi dan feedback yang diberikan dari media ini; (2) Validasi ahli berdasarkan aspek tampilan program, yang dimaksud dalam aspek tampilan program adalah seberapa menariknya desain antarmuka yang disajikan oleh media ini seperti kesesuaian animasi, pewarnaan, suara, grafis penggunaan bahasa dan yang lainnya yang menyangkut penampilan fisik dari media pendidikan kesehatan audio visual ini; (3) Validasi ahli berdasarkan aspek kualitas teknis, kualitas teknis yang dimaksud adalah prosedur penggunaan programnya serta hal-hal yang berkaitan dengan bagaimana pengguna dari media ini berinteraksi dalam mengaplikasikannya.

Hasil validasi ahli dari aspek pendidikan menunjukkan Mean I_CVI, item-level content validity index rata-rata $=1$, kemudian proporsi rata-rata dinilai relevan dari pakar pertama, kedua dan ketiga adalah 1.00. Ini berarti video edukasi incasting memiliki validitas yang sangat tinggi ditinjau dari aspek pendidikan dan sudah dapat digunakan sebagai media edukasi pada anak usia prasekolah. Hasil validasi ahli dari aspek tampilan program menunjukkan Mean I_CVI, item-level content validity index rata-rata $=0.95$, kemudian proporsi rata-rata dinilai relevan dari pakar pertama $=1.00$, pakar kedua $=1.00$, dan pakar ketiga $=0.86$. Ini berarti video edukasi incasting memiliki validitas yang sangat tinggi ditinjau dari aspek tampilan program dan dapat digunakan dengan revisi minimal. Hasil validasi ahli dari aspek kualitas teknis menunjukkan Mean I_CVI, item-level content validity index rata-rata $=1$, kemudian proporsi rata-rata dinilai relevan dari pakar pertama, kedua dan ketiga adalah 1.00. Ini berarti video edukasi incasting memiliki validitas yang sangat tinggi ditinjau dari aspek kualitas teknis dan sudah dapat digunakan sebagai media edukasi pada anak usia prasekolah.

Efektifitas dari video yang telah disusun adalah dengan melakukan intervensi secara langsung kepada populasi target dimana populasi pada penelitian ini adalah anak prasekolah PAUD di Kapanewon Kasihan Bantul. Intervensi dilakukan 4 kali pertemuan tatap muka secara online selama 1 bulan. Jumlah sampel dalam penelitian ini adalah 20 orang anak usia sekolah dengan menggunakan teknik purposive sampling. Besar sampel ditentukan 
menggunakan rumus besar sampel penelitian ekperimen yaitu rumus estimasi besar sampel untuk menguji hipotesis beda 2 rerata kelompok dependent.

Variabel yang diukur adalah asupan makan, perilaku cuci tangan dan status gizi balita. Instrumen yang digunakan untuk mengukur asupan makan adalah food record 24 jam, instrument untuk mengukur perilaku cuci tangan adalah ceklist cuci tangan 6 langkah. Pengukuran status gizi menggunakan indicator TB/U atau PB/U. Pengukuran tinggi badan anak usia diatas 2 tahun dilakukan dengan berdiri tegak menggunakan microtoise yang sebelumnya telah dikalibrasi. Analisis data menggunakan uji parametric untuk data numeric dan non parametric untuk data kategorik. Penelitian ini sudah lulus uji etik oleh komite etik penelitian FKIK UMY dengan No. 016/EC-KEPK FKIK UMY/I/2021.

\section{HASIL PENELITIAN}

Tabel. 1

Distribusi Frekuensi Responden Berdasarkan Jenis Kelamin dan Pendidikan Ibu $(\mathrm{n}=39)$

\begin{tabular}{lcc}
\hline \multicolumn{1}{r}{ Karakteristik Responden } & \multicolumn{2}{c}{ Kelompok Intervensi (n=20) } \\
& $\mathrm{f}$ & $\%$ \\
\hline Jenis kelamin & & 55 \\
$-\quad$ Laki-laki & 11 & 45 \\
$-\quad$ Perempuan & 9 & 5 \\
\hline Pendidikan Ibu & 1 & 50 \\
$-\quad$ SD-SMP & 10 & 45 \\
$-\quad$ SMA & 9 & \\
$-\quad$ PT & & 5 \\
\hline
\end{tabular}

Berdasarkan tabel 1 menunjukkan bahwa mayoritas resonden berjenis kelamin lakilaki yaitu sebanyak 11 responden (55\%) dan mayoritas berpendidikan SMA yaitu sebanyak 10 responden $(50 \%)$.

Tabel. 2

Gambaran Asupan Makan Responden pada Anak Usia Prasekolah Sebelum dan Setelah Intervensi $(n=20)$

\begin{tabular}{cccccc}
\hline \multirow{2}{*}{ Variabel Penelitian } & \multicolumn{2}{c}{$\begin{array}{c}\text { Sebelum Intervensi } \\
(\mathrm{n}=20)\end{array}$} & \multicolumn{2}{c}{$\begin{array}{c}\text { Setelah intervensi } \\
(\mathrm{n}=20)\end{array}$} & \multirow{2}{*}{$\mathrm{P}^{*}$} \\
& Min-Max & Mean \pm SD & Min-Max & Mean \pm SD & \\
\hline \multirow{2}{*}{ Asupan makan total } & \multirow{2}{*}{$450-1709$} & $\begin{array}{c}1064.85 \\
\pm 355.85\end{array}$ & $\begin{array}{c}836.18- \\
2233.10\end{array}$ & $\begin{array}{c}1377.07 \\
\pm 376.65\end{array}$ & \multirow{2}{*}{0.000} \\
& & \multirow{2}{*}{1354.95} & $206.60-$ & 442.99 & 0.028 \\
\multirow{2}{*}{ Asupan Makan Pagi } & \multirow{2}{*}{$131-638$} & \pm 143.57 & 673.55 & \pm 142.28 & \\
\hline \multirow{2}{*}{ Asupan Makan Siang } & \multirow{2}{*}{$131-637$} & 386.55 & $164.56-$ & 481.52 & \multirow{2}{*}{0.069} \\
& \multirow{2}{*}{ A30-502 } & 324.05 & $215.67-$ & 452.08 & \multirow{2}{*}{0.022} \\
\hline \multirow{2}{*}{ Asupan Makan Malam } & & \pm 125.30 & 1129.50 & \pm 228.67 & \\
& & & & & \\
\hline
\end{tabular}

Berdasarkan tabel 2 menunjukkan terdapat peningkatkan asupan makan total, makan pagi dan makan malam sedangkan pada asupan makan siang tidak terlihat perbedaan. 
Tabel. 3

Gambaran PHBS Perilaku Cuci Tangan pada Anak Usia Prasekolah Sebelum dan Setelah Intervensi $(\mathrm{n}=20)$

\begin{tabular}{lccccc}
\hline \multirow{2}{*}{ Variabel Penelitian } & \multicolumn{2}{c}{$\begin{array}{c}\text { Sebelum Intervensi } \\
(\mathrm{n}=20)\end{array}$} & \multicolumn{2}{c}{$\begin{array}{c}\text { Setelah intervensi } \\
(\mathrm{n}=20)\end{array}$} & \multirow{2}{*}{$\mathrm{P}^{*}$} \\
\cline { 2 - 5 } & Min-Max & Median \pm SD & Min-Max & Median \pm SD & \\
\hline $\begin{array}{l}\text { Perilaku Cuci } \\
\text { Tangan }\end{array}$ & $8-14$ & $12 \pm 2.03$ & $10-14$ & $14 \pm 1,45$ & 0,007 \\
\hline
\end{tabular}

Berdasarkan tabel 3 terlihat bahwa intervensi video edukasi pencegahan stunting dapat meningkatkan PHBS perilaku cuci tangan pada anak usia prasekolah di PAUD.

Tabel. 4

Gambaran Nilai Z Score dan Status Gizi pada Anak Usia Prasekolah Sebelum dan Setelah Intervensi $(n=20)$

\begin{tabular}{lccc}
\hline \multicolumn{1}{c}{ Variabel Penelitian } & Sebelum Intervensi & Setelah Intervensi & P \\
\hline Z Score & & & \\
$-\quad$ Min-Max & $-3,49-1.56$ & $-1,83-3,77$ & $0,020^{*}$ \\
$-\quad$ Mean \pm SD & $-0,619 \pm 1,39$ & $0,015 \pm 1,64$ & \\
\hline Status Gizi (F, $\%)$ & & & \\
$-\quad$ Sangat pendek & $1(5 \%)$ & & $0,034 * *$ \\
$-\quad$ Pendek & $3(15 \%)$ & $19(95 \%)$ & \\
$-\quad$ Normal & $16(80 \%)$ & $1(5 \%)$ & \\
$-\quad$ Tinggi & & & \\
\hline
\end{tabular}

Berdasarkan tabel 5 terlihat bahwa terdapat peningkatan nilai $\mathrm{Z}$ score dan status gizi setelah diberikan program PAUD incasting.

\section{PEMBAHASAN}

Peneliti mengembangkan dua media audio visual untuk pencegahan stunting pada anak usia prasekolah. Anak usia prasekolah merupakan periode emas tumbuh kembang dan perkembangan anak (Padila et al., 2019). Pada masa ini juga terjadi peningkatan kemampuan dalam membaca, hal ini berkaitan dengan perkembangan proses yang unik dari fungsi syaraf di otak yang dapat menangkap objek secara audio visual (Dinga et al., 2018). Penelitian-penelitian sebelumnya telah membuktikan bahwa media audio visual dapat meningkatkan kemampuan bahasa pada anak, peningkatan pengetahuan (Adawiyah et al., 2019; Br et al., 2020; Sasmitha \& Ilmi, 2017; Thorifah \& Umam, 2019).

Media audio visual yang telah dikembangkan oleh peneliti efektif sebagai media pencegahan stunting di PAUD dengan indikator terdapat peningkatan asupan makanan, perilaku mencuci tangan dan status gizi anak usia prasekolah. Hasil penelitian menunjukkan adanya peningkatan asupan makan total, pagi dan malam setelah diberikan intervensi menggunakan media audio visual sedangkan pada asupan makan siang tidak terjadi peningkatan. Hal ini disebabkan karena untuk mengubah perilaku anak dalam asupan makan dibutuhkan dukungan dari keluarga terutama sebagai penyedia bahan makanan dan sebagai contoh anak dalam berperilaku. Oleh karena itu dibutuhkan kerjasama antara pihak tenaga kesehatan, pendidikan dan keluarga dalam mendukung perubahan perilaku asupan makan anak (Dewi et al., 2019). 
Penelitian ini sejalan dengan penelitia Adawiyah et al., (2019) mendapatkan bahwa edukasi gizi dengan media video dapat meningkatkan pemahaman gizi pada anak usia 5-6 tahun dengan efektif. Penggunaan media dalam proses pembelajaran mampu mempermudah guru dalam menyampaikan materi, terlebih pada anak usia dini. Video merupakan salah satu media pembelajaran yang dapat digunakan pada lembaga pendidikan anak usia dini. Gambar dan suara yang muncul pada video yang menampilkan tayangan cerita dengan durasi singkat, diharapkan mampu membuat anak tidak cepat bosan, sekaligus merangsang minat mereka untuk belajar dan antusias terhadap cerita yang ditayangkan.

Hasil penelitian menunjukkan bahwa adanya peningkatan pengetahuan maupun keterampilan anak dalam perilaku cuci tangan setelah diberikan intervensi menggunakan media audio visual. Jenis media ini memiliki kemampuan yang lebih baik, karena melibatkan dua indera terbesar dalam penyerapan informasi, yaitu indera penglihatan dan pendengaran. Pendidikan kesehatan dengan menggunakan media audio visual dapat meningkatkan pengetahuan anak usia sekolah tentang cuci tangan karena media yang digunakan dapat menarik perhatian anak dengan menampilkan gambar nyata dan suara dari materi cuci tangan. Selain itu, materi penyuluhan yang ditampilkan dalam video juga mudah dipahami karena langsung pada inti pembahasan dan menggunakan kata-kata yang tidak sulit dimengerti (Sasmitha \& Ilmi, 2017).

Penelitian ini sejalan dengan penelitian Sasmitha \& Ilmi (2017) menyatakan bahwa terdapat pengaruh pendidikan kesehatan dengan audio visual terhadap pengetahuan tentang cuci tangan pada anak usia sekolah. Metode audio visual memiliki keunggulan karena dapat menyampaikan pengertian atau informasi dengan cara yang lebih konkrit atau lebih nyata daripada yang dapat disampaikan oleh kata-kata yang diucapkan. Sehingga seseorang menjadi antusias terhadap video yang diberikan tentang cuci tangan sehingga akan mempengaruhi pengetahuan orang tersebut. Hasil dalam penelitian ini menunjukkan bahwa terdapat peningkatan pengetahuan siswa setelah diberikan pendidikan kesehatan dengan audio visual.

Hasil penelitian menunjukkan bahwa terdapat peningkatan nilai $\mathrm{Z}$ score dan status gizi setelah diberikan edukasi menggunakan media audio visual. Menurut penelitian para ahli, indera yang paling banyak menyalurkan pengetahuan ke otak adalah indera penglihatan kurang lebih $75 \%$ sampai $87 \%$ dari pengetahuan manusia diperoleh atau disalurkan melalui indera penglihatan, $13 \%$ melalui indera pendengaran dan $12 \%$ lainnya tersalur melalui indera yang lain ( $\mathrm{Br}$ et al., 2020). Media audio visual menawarkan penyuluhan yang lebih menarik dan tidak monoton sehingga dapat meningkatkat nilai $\mathrm{Z}$ score dan status gizi anak.

Penelitian ini sejalan dengan penelitian $\mathrm{Br}$ et al., (2020) yang menyatakan bahwa terdapat pengaruh edukasi gizi menggunakan media audio visual (video) terhadap pengetahuan dan sikap gizi seimbang. Media edukasi berfungsi untuk mengerahkan indera sebanyak mungkin kepada suatu objek sehingga mempermudah persepsi. Media edukasi membuat seseorang dapat lebih mengerti informasi atau materi yang dianggap rumit menjadi lebih mudah.

\section{SIMPULAN}

Berdasarkan hasil penelitian dapat disimpulkan bahwa pengembangan media edukasi audio visual pada program PAUD dapat mencegah stunting pada anak prasekolah dengan indikator peningkatan asupan makan, PHBS perilaku cuci tangan dan status gizi anak. 


\section{SARAN}

Media audio visual dapat dijadikan sebagai sarana edukasi yang efektif untuk pencegahan stunting pada anak usia prasekolah di PAUD sehingga diharapkan media yang telah dikembangkan dapat digunakan sebagai salahsatu alat bantu pendidikan di semua PAUD khususnya di Kabupaten Bantul.

\section{DAFTAR PUSTAKA}

Adawiyah, E. R., Kurniati, E., \& Romadona, N. F. (2019). Efektivitas Pendidikan Gizi melalui Media Video dalam Meningkatkan Pengetahuan Gizi Anak Usia Dini. Edusentris, 4(1), 46. https://doi.org/10.17509/edusentris.v4i1.369

Astuti, R. (2018). Upaya Meningkatkan Kebersihan Anak Usia 5-6 Tahun Melalui Penggunaan Media Audio Visual di PAUD Cendekia Kecamatan Medan Helvetia Kota Madya Medan. http://repository.uinsu.ac.id/5510/

Br, H. D. T., Simanjuntak, B. Y., \& Wahyudi, A. (2020). Pengaruh Edukasi Gizi Menggunakan Media Audio Visual (Video) terhadap Pengetahuan dan Sikap Gizi seimbang. Jurnal Kesehatan Poltekkes Ternate, 13(1), 25-30. http://ejournal.poltekkesternate.ac.id/ojs/index.php/juke/article/view/151

Dewi, P. K. M., Srimiati, M., \& Septiani, S. (2019). Pengaruh Pendidikan Gizi (AudioVisual) terhadap Perilaku dan Asupan pada Siswa Sekolah Dasar. Jurnal Binawan, $1(1)$ 58-63. http://journal.binawan.ac.id/index.php/bsj/article/view/52/53

Dinga, S., Wu, D., Huang, S., Wu, C., Wang, X., Shi, J., Hu, Y., Liang, C., Zhang, F., Lu, M., Leiken, K., \& Xiang, J. (2018). Neuromagnetic Correlates of Audiovisual Word Processing in the Developing Brain. International Journal of Psychophysiology, 128, 7-21. https://doi.org/10.1016/j.ijpsycho.2018.03.016

Dinas Kesehatan Yogyakarta. (2020). Profil Kesehatan Kota Yogyakarta Tahun 2020 (Data Tahun 2019). https://kesehatan.jogjakota.go.id/uploads/ /profil_dinkes_2020_data_2019.pdf

Hartinger, S. M., Nuño, N., Hattendorf, J., Verastegui, H., Karlen, W., Ortiz, M., \& Mäusezahl, D. (2020). A Factorial Cluster-Randomised Controlled Trial Combining Home-Environmental and Early Child Development Interventions to Improve Child Health and Development: Rationale, Trial Design and Baseline Findings. BMC Medical Research Methodology, 20(1). https://doi.org/10.1186/s12874-020-00950-y

Hati, F. S., \& Lestari, P. (2016). Pengaruh Pemberian Stimulasi pada Perkembangan Anak Usia 12-36 Bulan di Kecamatan Sedayu, Bantul. Jurnal Ners dan Kebidanan Indonesia, 4(1), 44. https://doi.org/10.21927/jnki.2016.4(1).44-48

Huriah, T., Handayani, P., Sudyasih, T., \& Susyanto, B. E. (2021). The Determinant Factors of Stunting Among Children in Urban Slums Area, Yogyakarta, Indonesia. Open Access Macedonian Journal of Medical Sciences, 9(T4), 1-5. https://doi.org/10.3889/oamjms.2021.5593

Kemenkes. (2019). Profil Kesehatan Indonesia tahun 2018. Kementrian Kesehatan RI

Kemenkes RI. (2018). Situasi Balita Pendek (Stunting) di Indonesia. Kementerian Kesehatan RI, 301(5), 1163-1178

Kemenkes RI. (2019). Laporan Nasional Riskesdas 2018. Badan Penelitian dan Pengembangan Kesehatan. Badan Penelitian dan Pengembangan Kesehatan 
Mesiono, M., Vanni, S. O., \& Zairina, N. (2020). Pengaruh Penggunaan Media Audio Visual terhadap Perkembangan Kognitif Anak Usia 5-6 Tahun di TK Dwi Utama Deli Serdang. Jurnal Raudhah, 8(1), 58-68. http://jurnaltarbiyah.uinsu.ac.id/index.php/raudhah/article/view/586

Padila, P., Andari, F. N., \& Andri, J. (2019). Hasil Skrining Perkembangan Anak Usia Toddler antara DDST dengan SDIDTK. Jurnal Keperawatan Silampari, 3(1), 244-256. https://doi.org/10.31539/jks.v3i1.809

Perkins, J. M., Kim, R., Krishna, A., McGovern, M., Aguayo, V. M., \& Subramanian, S. V. (2017). Understanding the Association Between Stunting and Child Development in Low- and Middle-Income Countries: Next Steps for Research and Intervention. Social Science and Medicine, 193, 101-109. https://doi.org/10.1016/j.socscimed.2017.09.039

Prasko, P., Sutomo, B., \& Santoso, B. (2016). Penyuluhan Metode Audio Visual dan Demonstrasi terhadap Pengetahuan Menyikat Gigi pada Anak Sekolah Dasar. Jurnal Kesehatan Gigi, 3(2), 53-57. https://ejournal.poltekkessmg.ac.id/ojs/index.php/jkg/article/view/1784

Sasmitha, N. R., \& Ilmi, A. A. (2017). Peningkatan Pengetahuan tentang Cuci Tangan melalui Pendidikan Kesehatan dengan Media Audiovisual. Journal of Islamic Nursing, 2(2), 43. http://103.55.216.56/index.php/join/article/view/3980

Siswina, T., Shahib, N., \& Rasyad, A. S. (2016). Pengaruh Stimulasi Pendidikan terhadap Perkembangan Kecerdasan Anak Usia 3-6 Tahun. Jurnal Ilmiah Bidan, 1(2), 27-33. https://e-journal.ibi.or.id/index.php/jib/article/view/7/5

Thorifah, S. B. A. A., \& Umam, K. (2019). The Influence of Use Audio Visual Media to Increase the Development of Early Childhood Language. Jurnal Indria (Jurnal Ilmiah Pendidikan Prasekolah dan Sekolah Awal), 4(2), 146-155. https://doi.org/10.24269/jin.v4n2.2019.pp146-155

Titaley, C. R., Ariawan, I., Hapsari, D., Muasyaroh, A., \& Dibley, M. J. (2019). Determinants of the Stunting of Children Under Two Years Old in Indonesia: A Multilevel Analysis of the 2013 Indonesia Basic Health Survey. Nutrients, 11(5). https://doi.org/10.3390/nu11051106

Vasquez, N. A., \& Daher, J. (2019). Do Nutrition and Cash-Based Interventions and Policies Aimed at Reducing Stunting Have an Impact on Economic Development of Low-and-Middle-Income Countries? A Systematic Review. BMC Public Health, 19(1), 1419. https://doi.org/10.1186/s12889-019-7677-1

WHO. (2017). Stunted Growth and Development : Context, Causes and Consequences. World Health Organization, 4. www.who.int/nutrition/childhood_stunting_framework_leaflet_en.pdf

WHO. (2019). Child Stunting Data Visualizations Dashboard. WHO, 4(1). https://apps.who.int/gho/data/node.sdg.2-2-viz-1?lang=en 